\title{
Pemberdayaan Kader Posyandu Balita Melalui Model Three Level Marketing Deteksi Dini Kelainan Tumbuh Kembang Anak
}

\section{The employment of "Posyandu Balita" Cadre through Three Level Marketing Model for Early Detection of Child Growth and Development Anomaly}

Tutiek Rahayu*, Yuliati, Tri Harjana

Jurusan Pendidikan Biologi, FMIPA UNY, Email: tutikrahayu3@gmail.com

\begin{abstract}
Abstrak
Kegiatan PPM ini bertujuan untuk memberikan pengetahuan kepada kader posyandu balita dalam melakukan deteksi dini kelainan tumbuh kembang anak, untuk membantu mengembangkan keterampilan kader posyandu balita dalam melakukan deteksi dini tumbuh kembang anak, untuk menambah wawasan kader posyandu balita dalam hal kemampuan dasar untuk pencegahan dan penanggulangan kelainan tumbuh kembang anak. Pelaksanaan kegiatan PPM ini dengan ceramah tentang pertumbuhan fisik dan perkembangan psikologis anak, tata gizi anak serta penanggulangan kelainan tumbuh kembang anak, praktek deteksi dini, evaluasi pelaksanaan PPM untuk peserta (test dan non test). Kegiatan ini diikuti 27 kader posyandu balita yaitu $135 \%$ dari target yang ditetapkan yaitu 20 orang. Hasil kegiatan PPM menunjukkan adanya peningkatan penguasaan materi para peserta PPM sebelum dan sesudah mengikuti kegiatan tersebut, serta kemanfaatan PPM dinilai oleh peserta dengan instrument kepuasan pelanggan dari LPPM UNY menunjukan bahwa PPM ini sangat bermanfaat bagi para peserta.
\end{abstract}

Kata kunci: kader posyandu balita, model three level marketing ,deteksi dini, kelainan tumbuh kembang anak.

\begin{abstract}
PPM activity aims to give knowledge for "Posyandu Balita" cadre to early detection of child growth and development, to help develop "Posyandu Balita" cadre's skills to early detection of child growth and development, and to increase "Posyandu Balita" cadre's insight in basic ability to prevent and arrange child growth and development anomaly. The implementation of PPM with a lecture about child physic growth and phsicologic development, nutritionaly balanced menu for child, and child growth and development anomaly management the practice of early detection, evaluation of the implementation of PPM for participant (test and nontest) this activity was attaded by 27 "Posyandu Balita" cadres so that 135\% are met from 20 persons target. Result of PPM activities that show increased domination of the matter rated by before and after the PPM activities, as well as the benefit of PPM rated by participant with the instrument of customer satisfaction from LPPM UNY shows that PPM is very useful for the participants.
\end{abstract}

Keywords: "Posyandu Balita" cadre, three level marketing, early detection, child growth and development anomaly

\section{PENDAHULUAN}

Anak yang sehat dan cerdas serta tampan dan cantik dengan akhlak mulia merupakan idaman setiap keluarga.Upaya memiliki anak yang diharapkan tersebut harus dilakukan seorang calon ibu atau bapak sejak mereka memilih calon pasangan hidup, namun hal ini yang sering menerapkan prinsip bibit bobot bebet sering dilupakan.

Seorang anak yang terlahir di dunia sangat memerlukan dukungan faktor bawaan/genetik dan faktor lingkungan 
biologi, fisik, psikologi dan sosial. Jalinan yang baik pada kedua faktor diatas dalam masa proses pertumbuhan dan perkembangan anak akan menghasilkan seorang anak yang didambakan orangtua. Perhatian pada faktor-faktor yang mempengaruhi tumbuh kembang anak sejak dalam kandungan ibunya dan setelah lahir sangat diperlukan untuk mendapatkan anak yang didambakan tersebut.

Pemantapan perhatian terhadap tumbuh kembang anak harus dilaksanakan untuk mendapatkan sumber daya yang berkualitas. Anak yang berkualitas tidak akan mengalami kelainan. Ibu merupakan pengasuh utama anak yang dapat memantau pertumbuhan dan perkembangan anak.Kader Posyandu Balita yang melakukan penimbangan anak dan penyuluhan kesehatan pada ibu setiap bulan sangat memerlukan pengetahuan tentang deteksi dini kelainan tumbuh kembang anak.

Menurut Maslan Robert dalam [1] Yuliati (2008: 5) salah satu model pembelajaran yang bisa digunakan dalam peningkatan pengetahuan pada kader Posyandu Balita tentang deteksi dini kelainan tumbuh kembang anak adalah model Three Level Marketing. Model ini dimaksudkan agar peserta didik yang telah menguasai materi di atas dapat pembelajaran yang lain, yaitu masyarakat disekitarnya terutama pada ibu yang mempunyai anak balita dan remaja putri yang merupakan calon ibu.

Desa Krakitan, Bayat, Klaten mempunyai 6 Posyandu Balita dengan 60 kader aktif. Materi tentang tumbuh kembang anak merupakan salah satu materi yang diminta para kader pada waktu dilakukan pengabdian masyarakat pada tahun 2014 karena mereka merasa belum cukup pengetahuan dan keterampilan tentang masalah tersebut. Selain itu Desa Krakitan Kecamatan Bayat juga merupakan desa yang luasnya tiga kali desa lainnya di Kabupaten Klaten, sehingga penduduknya juga tiga kali penduduk desa-desa lainnya.
Berdasarkan latar belakang di atas, maka pengabdi dari Jurusan Pendidikan Biologi FMIPA UNY bermaksud membantu upaya posyandu balita Desa Krakitan dalam memberdayakan anggotanya dalam mengelola posyandu balita dengan cara memberikan pelatihan tentang pengetahuan deteksi dini kelainan tumbuh kembang anak. Kegiatan ini diharapkan dapat meningkatkan pengetahuan Deteksi dini kelainan tumbuh kembang anak, sehingga mereka terampil melakukan deteksi tersebut dan menyebarluaskan pengetahuan tersebut pada masyarakat di sekitar mereka.

\section{SOLUSI DAN TEKNOLOGI}

Solusi dan teknologi yang digunakan oleh Tim untuk mengatasi persoalan tersebut diantaranya adalah:

1. Persiapan: Tahap persiapan dilakukan dengan cara diskusi kebutuhan materi pelatihan dengan pengurusan posyandu balita, ibu Dukuh dan ibu-ibu PKK desa Krakitan, Bayat, Klaten. Setelah itu dilakukan sosialisasi pada kader posyandu, pengiriman undangan dan dilakukan rapat koordinasi Tim Pengabdi untuk persiapan pelaksanaan PPM

2. Pelaksanaan: Peserta pelatihan mendapatkan pemateri melakukan diskusi dengan tanya jawab terkait kelainan tumbuh kembang anak. Peserta pelatihan mendapatkan paparan materi kelainan tumbuh kembang anak berupa 3 materi yang terdiri dari Pertumbuhan fisik dan perkembangan psikologis anak yang disampaikan oleh drh. Tri Harjana; tata gizi untuk anak yang disampaikan oleh Yuliati, M.Kes dan materi penanggulangan kelainan tumbuh kembang anak yang disampaikan oleh dr. Tutiek Rahayu, M.Kes.

3. Evaluasi dan perbaikan: evaluasi dilaksanakan berdasarkan aktivitas keberhasilan proses pelaksanaan PPM, peningkatan pengetahuan, ketrampilan 
serta kemanfaatan bagi seluruh peserta yang mengikuti kegiatan PPM.

\section{HASIL DAN DISKUSI}

Pelaksanaan kegiatan meliputi beberapa tahap yaitu tahap persiapan, pemberian materi, tanya jawab, lomba, pengisian angket, pelaksanaan posttest dan penutup. Persiapan kegiatan dilakukan dengan cara berkoordinasi dengan pengurus posyandu balita, ibu dukuh dan ibu-ibu PKK Desa Krakitan, Bayat, Klaten terkait kebutuhan materi pelatihan. Selanjutnya dilanjutkan dengan sosialisasi kepada seluruh kader posyandu dan pengiriman undangan. Kegiatan PPM dilaksanakan di Balai Desa Krakitan, Bayat, Klaten pada tanggal 6 Oktober jam 12.45 sampai 15.30.

Pelaksanaan kegiatan PPM diawali dengan pendafataran peserta, pembacaan susunan acara, sambutan dari ketua pelaksana PPM, sambutan ibu ketua PKK Desa Krakitan, Bayat, Klaten, kemudian pelaksanaan pretest dan dilanjutkan dengan penyampaian materi oleh Tim PPM. Setelah semua materi disampaiakan para peserta kemudian diberi kesempatan bertanya jawab pada sesi Tanya jawab, dan selanjutnya adalah lomba. Kegiatan selanjutnya adalah pengisian angket kepuasan pelanggan yang sudah disiapkan, salah satu tujuannya adalah untuk mengukur keberhasilan kegiatan PPM. Selain itu juga dilaksanakan posttest. Penutupan dilakukan dengan doa secara individu.

Jumlah peserta dalam kegiatan PPM ini adalah sebanyak 27 orang atau 135\% dari target perserta yang ditetapkan yatiu 20 peserta. Indikator keberhasilan pelaksanaan kegiatan salah satunya dilihat berdasarkan pemahaman para perserta kegiatan yang diukur berdasarkan nilai rata-rata pretest dan posttest para peserta PPM. Hasil pretest dan posttest tersebut disajikan dalam gambar satu.

Nilai rata-rata pretest pada peserta kegiatan adalah sebesar 57,75 dengan skala 10-100. Hal tersebut mengalami peningkatan sebesar 18,5 point setelah mengikuti kegiatan PPM yang dinilai dengan posttest. Nilai rata-rata posttest adalah sebesar 76,25 skala 10-100. Peningkatan nilai rata-rata tersebut merupakan salah satu indikator keberhasilan kegiatan PPM yaitu adanya peningkatan nilai rata-rata posttest yang lebih dari 70. Pengukuran penguasaan materi secara individual untuk 27 orang peserta.

Indikator keberhasilan lainnya adalah banyak dan beragamnya pertanyaan yang dilakukan oleh para peserta dan dapat menggambarkan keberhasilan pelaksanaan PPM ini. Pertanyaan paling banyak ditujukan pada materi pencegahan kelainan tumbuh kembang anak. Keingintahuan para peserta sangat besar tampak pada antusiasme, mereka berebut ingin menjawab pertanyaan-pertanyaan yang dilombakan. Setiap pembicara mengajukan 2 pertanyaan dan kesemua soal bisa dijawab dengan benar oleh peserta yang ditunjuk oleh pembicara, sehingga 6 peserta yang menjawab dengan benar mendapakan hadiah lomba.

Tahap pelatihan meliputi pemberian materi yang disampaikan oleh tim PPM. Terdapat 3 topik materi terkait kelainan tumbuh kembang anak yang dsampaikan kepada peserta yaitu materi tentang pertumbuhan fisik dan perkembangan psikologis anak yang disampaikan oleh drh. Tri Harjana M.P. Selain itu juga disampaikan tentang tata gizi untuk anak yang disampaikan oleh Yuliati, M.Kes juga tentang penanggulangan kelainan tumbuh kembang anak yang disampaikan oleh dr. Tutiek Rahayu, M.Kes. Pelatihan deteksi dini juga diberikan kepada para peserta yaitu pelatihan keterampilan ibu-ibu peserta kegiatan dalam mendeteksi dini kelainan tumbuh kembang anak dengan menggunakan pedoman deteksi dini. Tumbuh Kembang anak sudah dimulai sejak bertemunya spesrma dengan sel telur sampai dewasa. Pertumbuhan fisik pada anak dapat dinilai menggunakan antopometri. Hasil pengukuran 
antropometri dibandingkan dengan suatu baku tertentu, misalnya NHCS Harvard atau baku nasional. Perbandingan angka dengan baku akan dapat diketahui status gizi dari anak tersebut yang merupakan tolok ukur penilaian pertumbuhan anak menunjukkan posisi anak pada suatu saat, yaitu pada persentil seberapa untuk suatu ukuran antropometri pertumbuhan sehingga dapat ditentukan apakah corak/pola pertumbuhannya (Dewa Nyoman Supariasa, 2001).

Selain itu terdapat juga pertumbuhan organ-organ reproduksi yang penting untuk diketahui. Pertumbuhan organ-organ reproduksi mengikuti pola pertumbuhan genital, dimana pertumbuhan lambat pada pra remaja, kemudian disusul pacu tumbuh remaja yang pesat.Pada masa remaja terjadi pertumbuhan lebih lanjut pada pertumbuhan tungkai memanjang dan melebar, dan pertumbuhan terus berlangsung sampai epifise menutup dan pertumbuhan tinggi berhenti. Pada anak laki-laki pacu tinggi badan dimulai kirakira setahun setelah pembesaran testis dan mencapai maksimum dan disertai tumbuhnya rambut pubis pada stadium 3 3. Soetjiningsih dan IG.N Gde Ranuh, (2013); [4] Roy Meadow \& Simon Newell (2002).

Indikator keberhasilan untuk evaluasi kemanfaatan kegiatan PPM ini diukur dari pernyataan peserta terhadap kegitan PPM menggunakan instrumen kepuasan pelanggan yang disusun oleh LPPM UNY. Adapun hasilnya adalah disajikan dalam tabel 1. Tabel tersebut menunjukkan bahwa PPM ini sangat bermanfaat bagi para peserta karena semua pernyataan mendapatkan nilai skor lebih dari 3, sangat jauh dari nilai baik yang hanya menargetkan $80 \%$ mendapatkan skor.

\section{KESIMPULAN}

Berdasarkan uraian hasil dan diskusi maka dapat di simpulkan sebagai berikut:

1. Peningkatan pengetahuan kader posyandu balita dalam melakukan deteksi dini kelainan tumbuh kembang anak dapat dilakukan dengan pembelajaran materi masalah tersebut.

2. Pengembangan keterampilan kader posyandu balita dalam melakukan deteksi dini kelainan tumbuh kembang anak dapat dilakukan dengan pelatihan dan lomba.

3. Penambahan wawasan kader posyandu balita dalam hal kemampuan dasar untuk penanggulangan kelainan tumbuh kembang dapat dilakukan dengan pembelajaran materi, pelatihan dan lomba.

Berdasarkan hal tersebut, saran untuk kedepannya adalah Pelaksanaan PPM dengan waktu yang lebih lama dengan cakupan pada kader balita yang lebih banyak perlu diupayakan.

\section{$\begin{array}{lll}\text { No } & \text { PERNYATAAN } & \text { Skor }\end{array}$}

1. Kesesuain kegiatan pengabdian dengan kebutuhan masyarakat 3,08

2. Kerjasama pengabdi dengan masyarakat 3,28

3. Memunculkan aspek pemberdayaan masyarakat 3,92

4. Meningkatkan motivasi masyarakat untuk berkembang 3,52

5. Sikap/perilaku pengabdi di lokasi pengabdian 3,32

6. Komunikasi/koordinasi LPPM dengan penanggungjawab lokasi pengabdian 3,08

7. Kesesuian waktu pelaksanaan dengan kegiatan masyarakat 3,24

8. Kesesuaian keahlian pengabdi dengan kegiatan pengabdian 3,04

9. Kemampuan mendorong kemandirian/swadaya masyarakat 3,36

10. Hasil pengabdian dapat dimanfaatkan masyarakat 3,44

Keterangan makna skor: $1=$ kurang; $2=$ cukup; 3 =baik; 4= sangat baik. 


\section{UCAPAN TERIMA KASIH}

Ucapan terima kasih kami haturkan kepada Kepala Desa Krakitan, Tim Penggerak PKK Desa krakitan, Ketua Kader KesehatanBalita Desa Krakitan dan Dekan FMIPA UNY.

\section{PUSTAKA}

Yuliati. 2008. Workshop Pengembangan Strategi dan Bahan Ajar Kesehatan Reproduksi Remaja Berbantuan
Komputer Bagi Guru Biologi di SMP. Laporan PPM: LPM UNY. Yogyakarta

I Dewa Nyoman Supariyasa, 2001.Penilaian Status Gizi. Penerbit Buku Kedokteran EGC. Jakarta

Soetjiningsih dan IG.N.Gde Ranuh. 2013. Tumbuh Kembang Anak. Penerbit Buku Kedokteran EGC. Jakarta.

Roy Meadow dan Simon Newel. 2002. Lecture Notes Pediatrica. Penerbit Erlangga. Jakarta. 